\title{
Efektifitas Pemakaian Aplikasi Katakana Memory Hint Dalam Mata Kuliah Shokyuu Moji Goi Zenhan
}

\author{
Rita Arni $^{1}$ \\ Fakultas Bahasa dan Seni, Universitas Negeri Padang, Sumatera Barat, Indonesia \\ Jl. Prof. Dr. Hamka, Air Tawar Barat, Kec. Padang Utara, Kota Padang, Sumatera Barat 25171 \\ E-mail: ritaarni@fbs.unp.ac.id
}

\begin{abstract}
Abstrak
Penelitian ini tentang keefektifan aplikasi Android Katakana Memory Hint dalam pembelajaran huruf Jepang atau pada mata kuliah Shokyuu Moji Goi Zenhan, pada mahasiwa tingkat satu Prodi Pendidikan Bahasa Jepang Universitas Negeri Padang. Penelitian ini difokuskan pada salah satu huruf Jepang yaitu huruf Katakana. Alasan peneliti memilih huruf ini, karena huruf Katakana merupakan huruf yang sulit dipahami. Bagi pembelajar bahasa Jepang pemula atu pembelajar tingkat dasar, tentunya memerlukan media untuk membantu mempermudah mempelajari huruf Katakana. Oleh karena itu, diujicobakan media yang menarik, efektif, efisien serta menyenangkan yaitu aplikasi Katakana Memory Hint. Aplikasi ini, berbasis Android sehingga mahasiswa bisa menggunakan pada Smartphone masing-masing serta bisa digunakan kapanpun dan dimanapun sebagai media untuk belajar huruf Katakana. Pada aplikasi ini, tidak hanya belajar tentang cara penulisan huruf tetapi juga disertai dengan contoh kosakata untuk latihan membaca Katakana dan tes untuk melatih kemampuan menulis dan membaca Katakana. Tujuan penelitian ini adalah untuk mendeskripsikan efektifitas dan mendekripsikan respon mahasiswa terhadap pemakaian aplikasi Katakana Memory Hint dalam pembelajaran huruf Katakana. Hal inilah yang latar belakang penelitian ini, untuk bisa memanfaatkan aplikasi Android Katakana Memory Hint karya Japan Foundation. Penelitian ini menggunakan metode ekperimen. Responden dalam penelitian ini adalah mahasiswa tingkat satu Prodi Pendidikan Bahasa Jepang Universitas Negeri Padang dan sampel penelitian yang berjumlah 30 orang. Dari hasil uji coba menunjukkan keefektifan aplikasi Andoroid Katakana Memory Hint bisa membantu mahasiswa untuk membaca dan menulis katakana.
\end{abstract}

Kata Kunci : Huruf Jepang, Katakana, Aplikasi Katakana Memory Hint

\begin{abstract}
This research is about the effectiveness of an Android application called the Katakana Memory Hint in learning Japanese letters during the Shokyuu Moji Goi Zenhan course. The course is taken by first-year students of the Japanese Language Education Study Program of Universitas Negeri Padang. This research focuses on one of the Japanese characters, the Katakana letters, because they are difficult to understand. For basic level learners, of course, they need media to help make it easier to learn the Katakana letters. Therefore, Katakana Memory Hint application was tested as an interesting, effective and efficient medium. Since this application is Android based, it can be used by the college students on their own Smartphone whenever and wherever they are to study Katakana. On this application, not only learning about how to write the letters, but also it is completed by examples of vocabulary to do Katakana reading practice and tests to practice writing skills and reading skills. This research was to describe the effectiveness and the college students' responses on the use of Katakana Memory Hint application in Learning Katakana. This research is done to find out the advantages of an Android application called the Katakana Memory Hint designed by the Japan Foundation. This research applied the experimental method. The respondents were first-year students of the Japanese Language Education Study Program of Universitas Negeri Padang with the number of research sample of 30 people. The research findings show that the application is, as a matter of fact, effective in helping students to read and write the Katakana letters.
\end{abstract}

Keywords: Japanese Characters, the Katakana Letters, the Katakana Memory Hint Application

\section{Pendahuluan}

Ketika mempelajari, mendalami yang penting bahkan adalah hal yang harus bahasa Jepang, huruf merupakan sesuatu dipelajari secara mutlak dalam proses 
Tersedia online di http://ejournal.undip.ac.id/index.php/kiryoku

belajar mengajar. Menurut Sadewa (2019: 13) huruf Hiragana (ひらがな) dipakai untuk menuliskan segala sesuatu yang berasal dari Jepang seperti kosakata murni bahasa Jepang, untuk membantu cara membaca huruf Kanji, menuliskan partikel, kata kerja dan lain-lain(Amat et al., 2017). Huruf Katakana (カタカナ) dipakai untuk menuliskan kosakata yang datang dari bahasa asing seperti nama orang asing seperti Suharto (スハルト), Obama (オバ マ), Rina (リナ) dan lain-lain, dipakai untuk menuliskan nama negara seperti Indonesia (インドネシア), Amerika (ア メリカ), Kanada (カナダ), dipakai untuk menuliskan nama kota asing seperti Padang (パダン), Jakarta（ジャカルタ）, Roma (ロマ), dipakai sebagai penegas pada sebuah kalimat, serta dipakai juga untuk menuliskan Onomatope. (Jianti et al., 2016) Huruf Kanji (漢字) dipakai untuk mempermudah intonasi dan jeda pada kalimat. kalau seluruhnya dituliskan dalam Huruf Hiragana atau huruf Katakana akan susah untuk memastikan intonasi serta jeda karena tidak memiliki spasi. Romaji (ロー マ字) huruf Romaji adalah huruf latin ( A Z) yang dipakai dalam penulisan seperti singkatan atau untuk penulisan bahasa asing yang dirasa perlu ditulis dalam bahasa aslinya (huruf latin) (PAPILAJA, n.d.).

Bahasa Jepang mempunyai banyak perbedaan dengan bahasa Indonesia terutama tentang huruf. Pada bahasa Jepang memakai empat jenis huruf sedangkan pada bahasa Indonesia sehari-hari hanya menggunakan huruf Alfabet atau huruf Latin. Hal ini yang menjadi faktor kesulitan dalam mempelajari bahasa Jepang khususnya bagi pembelajar bahasa Jepang pemula atau pembelajar tingkat dasar. Dari penelitian yang telah dilaksanakan oleh Hardiansyah (2012) tentang huruf
Katakana peserta didik mengalami kesulitan membedakan bentuk huruf Katakana yang mirip contoh huruf tsu (ツ) dengan huruf shi (シ), huruf ru (ル) dengan huruf re (レ), huruf n (ソ) dengan huruf so (ソ).

Fungsi huruf Katana untuk menulis kosakata atau ungkapan yang berasal dari bahasa asing dan sering juga diketahui sebagai tulisan laki-laki karena mempunyai arti penegasan dengan bentuk garis yang tegas (Mulyana Adimihardja, n.d.). Katakana dasar bahasa Jepang berjumlah 46 huruf, masing-masing huruf memiliki kaidah cara baca serta aturan penulisan. Huruf ini, juga berdasarkan suku kata. Beberapa lafal bahasa asing tidak dapat dituliskan secara sempurna karena ucapan kata-kata asing berbeda-berbeda didalam bahasa Jepang. Sebagai contoh, huruf L dan $\mathrm{R}$ diucapkan dengan bunyi yang sama kedalam bahasa Jepang. kemudian kata kata yang panjang juga sering diperpendek. Menurut J.Sasmita (2019:12) beberapa aturan dalam menulis huruf Katakana.

1. Untuk konsonan dobel Katakana juga memakai tsu kecil「ッ」

Misalnya:

$$
\begin{aligned}
& \text { Jetto : ジェット = jet } \\
& \text { Chekku: チェック = cek }
\end{aligned}
$$

2. Untuk Katakana vokal panjang memakai tanda $\lceil-」$

Misalnya:

$$
\begin{aligned}
& \text { Kaado : カード = kartu } \\
& \text { Giita : ギータ }=\text { gitar }
\end{aligned}
$$

Pada era globalisasi saat sekarang ini, hampir sebagian besar orang telah mempunyai Smartphone serta telah terbiasa memakai internet. Pengguna Smartphone didominasi oleh anak muda yaitu mahasiswa. Perkembangan teknologi yang semakin pesat, ditemukan Inovasi baru dalam dunia teknologi. Sama halnya dengan dunia pendidikan juga mengalami perubahan, sudah banyak pembelajaran yang menggunakan teknologi. Sejalan 
Tersedia online di http://ejournal.undip.ac.id/index.php/kiryoku

dengan perkembangannya banyak tempat kursus, sekolah serta universitas yang telah menggunakan pembelajaran digital. Satu contoh dari pembelajaran digital adalah aplikasi Smartphone sebagai media bantu proses pembelajaran. Menurut hasil penelitian yang telah dilaksanakan oleh Barakati (2013:11) tentang dampak penggunaan Smartphone bagi mahasiswa, hasil penelitian menunjukkan Smartphone memiliki tiga dampak positif yaitu, pertama dampak portabilitas merupakan dampak yang praktis karena Smartphone bisa dipakai dimanapun dan kapanpun sebagai sarana untuk belajar. Kedua dampak kolaborasi merupakan bisa memberikan informasi dengan memakai media sosial, ketiga dampak memotivasi, ini merupakan pengaruh dari dampak portabilitas Smartphone bisa dipakai dimanapun dan kapanpun mahasiswa menjadi lebih termotivasi.

Pemakaian perangkat Mobile, terutama pada Smartphone dapat berguna untuk tujuan teoritis dan sebagai media penunjang pembelajaran di dalam kelas (Aribowo 2015 : 13). Smartphone berbasis Android tentunya dapat digunakan untuk mempermudah pembelajaran sehingga pembelajaran pun terkesan lebih menarik. Media pembelajaran berbasis digital dalam hal ini Mobile Learning berbasis Android sudah banyak sekali menawarkan berbagai macam aplikasi yang dapat digunakan oleh dosen maupun mahasiswa untuk pembelajaran, yang tersedia di Playstore dan dapat diunduh serta dapat dijadikan sebagai alternatif media pembelajaran, misalnya pembelajaran bahasa Jepang. Salah satunya adalah aplikasi Memory Hint yang terbagi ke dalam tiga aplikasi sesuai jumlah dan jenis huruf Jepang yaitu Hiragana Memory Hint merupakan aplikasi dan media yang bisa digunakan untuk belajar huruf Hiragana, Katakana Memory Hint merupakan aplikasi dan media untuk belajar huruf Katanana, dan Kanji Memory Hint yang berguna untuk belajar huruf Kanji. ketiga aplikasi tersebut di produksi oleh Japan Foudation. (Kurniasih, 2016)

Dilihat data diatas, dapat disimpulkan lebih dari separuh pengguna Smartphone adalah mahasiswa (Gifary, 2015). Alasan mendasar peneliti menggunakan aplikasi Katakana Memory Hint sebagai data penelitian adalah karena aplikasi ini, sudah teruji validitasnya. Selain itu, memiliki banyak keunggulan seperti konten yang ada pada aplikasi ini mempunyai animasi yang menarik, suara serta ilustrasi yang sangat membantu untuk mengingat huruf Katakana, ada kuis yang bermanfaat untuk mengevaluasi huruf Katakana yang sudah dipelajari, penjelasan yang mudah dan menyenangkan tentang cara penulisan huruf, dilengkapi juga dengan tabel huruf Katakana yang bermanfaat untuk mendengarkan pelafalan huruf Katakana, serta Kompatibilitas untuk semua Android.

Penelitian ini dilakukan karena banyaknya penggunaan Smartphone dikalangan mahaiswa. Berdasarkan penelitian yang dilakukan oleh balitbangsdm.kominfo.go.id pada tahun 2017 kepada 6245 responden berdasarkan usia disimpulkan bahwa pengguna Smartphone terbanyak di Indonesia yaitu antara usia 20-29 tahun sebanyak 79,95\% itu artinya pengguna Smartphone di Indonesia di dominasi oleh kaum muda termasuk mahasiswa, sedangkan kalau hasil penelitian yang sama berdasarkan pekerjaan yaitu pelajar atau mahasiswa menempati urutan ke lima terbanyak setelah PNS/TNI/Polri, Karyawan Swasta, perangkat desa non PNS/Honorer dan Wiraswasta sebanyak 70,98\%. (KOMINFO, 2017)

Sebelumnya sudah ada penelitian yang serupa dengan penelitian ini, yaitu penelitian Mustika (2017) tentang pembelajarn Kanji dengan menggunakan aplikasi Kanji Memory Hint. Hasil penelitian menyatakan bahwa pembelajaran dengan memakai aplikasi Android Kanji 
Tersedia online di http://ejournal.undip.ac.id/index.php/kiryoku

memory Hint efektif dipakai untuk membaca serta menulis Kanji, hal ini terbukti dengan adanya peningkatan kemampuan nilai mahasiswa setelah diterapkan pemakaian aplikasi Kanji Memory Hint pada perkuliahan. Selain itu, penelitian serupa juga dilakukan oleh Rasiban (2017) juga pada mata kuliah Kanji dengan menggunakan aplikasi Kanji memory Hint, dari hasil penelitian terdapat peningkatan pemahaman makna Kanji melalui mnemonic image. Perbedaan penelitian ini dengan penelitian sebelumnya adalah, selain subjek penelitian yang berbeda, juga jenis huruf yang diteliti juga berbeda yaitu huruf Katana. Selain itu, juga untuk mengetahui bagaimana persepsi mahasiswa tentang penerapan aplikasi Katakana Memory Hint selama pembelajaran huruf Katakana dalam perkuliahan.

Penelitian ini difokuskan untuk menjawab pertanyaan berikut

1. Apakah penerapan penggunaan aplikasi Katakana Memory Hint efektif dipakai dalam mata kuliah Shokyuu Moji Goi Zenhan

2. Bagaimana persepsi mahasiswa tentang penerapan Aplikasi Katakana Memory Hint?

\section{Metode Penelitian}

Penelitian ini digolongkan ke quasi ekperimental resarch dengan disain penelitian pretest-posttest control group design. Ada satu kelas yang terdiri dari 30 mahasiswa yang dilibatkan dalam penelitian ini, yaitu mahasiswa tingkat satu yang mengambil mata kuliah Shokyu Moji Goi Zenhan di Prodi Pendidikan Bahasa Jepang Universitas Negeri Padang pada semester Juli - Desember 2020. Sample penelitian diambil melalui Purposive Sampling yaitu memilih salah satu kelas sebagai sample dengan alasan tertentu (Sugiyono: 2013). Sampel yang digunakan pada penelitian ini adalah kelas JPG1 2020 yang berjumlah 30 orang mahasiswa.
Alasan kelas JPG1 2020 dijadikan sebagai subjek penelitian adalah karena kelas ini merupakan kelas yang mempelajari huruf Katakana pada mata kuliah Shokyuu Moji Goi Zenhan. Selain itu, peneliti memerlukan satu kelas yang dapat mewakili satu karakteristik populasi. Maka, peneliti mengambil kelas JPG1 2020 sebagai objek penelitian karena kelas tersebut dianggap telah mampu untuk mewakili karakteristik populasi yang diinginkan. Melalui penelitian ini, peneliti juga ingin mengetahui persepsi mahasiswa mengenai penggunaan aplikasi Katakana Memory Hint untuk meningkatkan keterampilan Katakana melalui pengisian angket.

Penelitian ini dilakukan pada mata kuliah Shokyu Moji Goi Zenhan di Prodi Pendidikan Bahasa Jepang Universitas Negeri Padang pada semester Juli Desember 2020. Desain penelitian tergambar pada diagram berikut:

$\underline{\mathrm{O}}_{1}$

Gambar: Desain Penelitian (One Group Pretest-Posttest Design)

Keterangan:

$\begin{array}{ll}\mathrm{O}_{1} & : \text { pretest } \\ \mathrm{X} & : \text { treatment } \\ \mathrm{O}_{2} & \text { : posttest }\end{array}$

\section{Hasil Dan Pembahasan 3.1.Data Tes}

Data penelitian yang berupa tes, yaitu pretest dan posttet. Pretest bertujuan mengetahui kemampuan huruf Katakana mahasiswa Prodi Pendidikan Bahasa Jepang sebelum pengunaan aplikasi Katakana Memori Hint diterapkan, sementara posttest dimaksudkan untuk melihat capaian kemampuan Katakana mereka setelah treatment diberikan. Hasil kedua tes akan dibandingkan untuk mengetahui keefektifan aplikasi Katakana Memory Hint dalam meningkat kemampuan huruf Katakana mahasiswa. 
Sebelumnya peneliti telah malakukan uji normalitas, hasil uji coba normalitas bisa dilihat sebagai berikut.

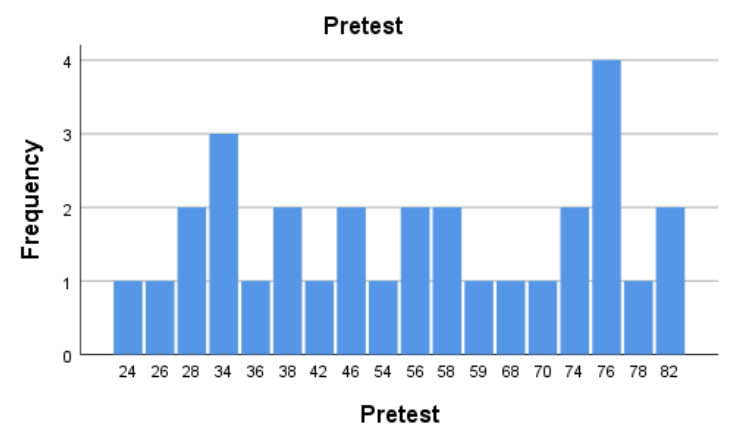

Dari data terlihat bahwa Histogram berbentuk simetris yang mengindikasikan bahwa data berdistribusi normal dengan nilai rata-rata 54,23 dan standar deviasi 19.244. Selanjutnya untuk membuktikan bahwa data berdistribusi normal juga dapat dilihat dari plot kenormalan.

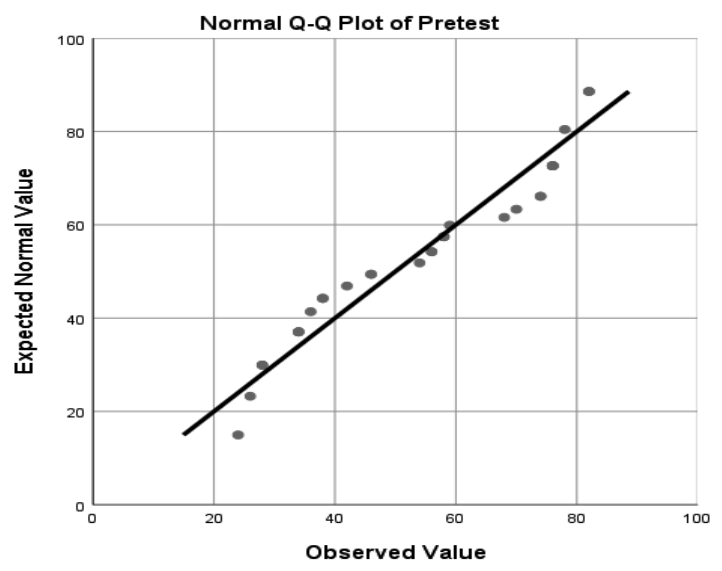

Dari normal Q-Q Plot terlihat bahwa plot-plot mengikuti garis linier (berada disekitaran garis linier) dan tidak ada plot yang terletak jauh dari garis linier. Dengan demikian data dapat disimpulkan terdistribusi normal. Setelah data berdistribusi normal, peneliti kemudian menganalisis hasil pretest. Nilai rata-rata siswa pada prestest adalah 54,23 dimana nilai tertinggi 82 dan nilai terendah 24 . Hasil ini menunjukkan bahwa kemampuan pengguasaan huruf Katakana mahasiswa masih rendah.

Setelah enam kali pertemuan, posttest kemudian diberikan kepada mahasiswa. Hasil tes menunjukkan bahwa nilai rata-rata mahasiswa adalah 83,53 dengan nilai yang paling tinggi adalah 98 dan nilai yang paling rendah adalah 60 . Untuk mengetahui signifikansi peningkatan kemampuan penguasaan Katakana mahasiswa dari 54,23 pada pretest menjadi 83,53 pada postest, peneliti melakukan $T$ Paired Test. Hasil tes tersebut terlihat pada gambar dibawah ini:

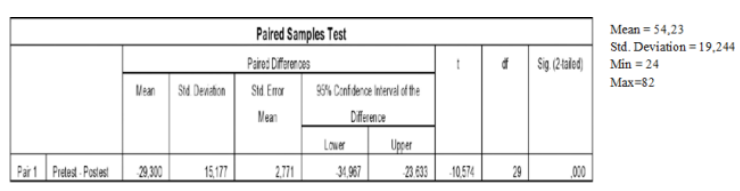

Setelah dilihat pada tabel menunjukkan bahwa nilai Sig. (2-tailed) adalah 000 yang lebih kecil dari 0,05. Hasil ini menunjukkan bahwa adanya variasi yang mencolok nilai pretest dan nilai posttest mahasiswa. Hal ini juga menandakan bahwa penggunaan aplikasi Katakana Memory Hint bisa membantu mahasiswa dalam mata kuliah Shokyuu Moji Goi Zenhan.

\subsection{Hasil Data Angket}

Data yang diperoleh melalui angket, menggambarkan sepuluh point yang berkaitan dengan persepsi mahasiswa mengenai penerapan penggunaan aplikasi Katakana Memory Hint pada kelas Shokyu Moji Goi Zenhan di Prodi Pendidikan Bahasa Jepang Universitas Negeri Padang. Jawaban butir soal angket atau respon yang diberikan oleh mahasiswa bisa dilihat pada diagram berikut. 


\section{Indikator 1: Analisis Keefektifan Aplikasi Andoroid Katakana Memory Hint}

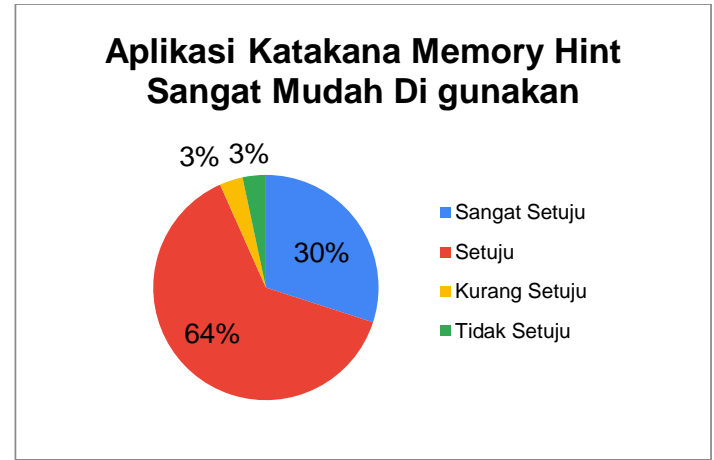

Gambar 1: Respon angket Butir 1

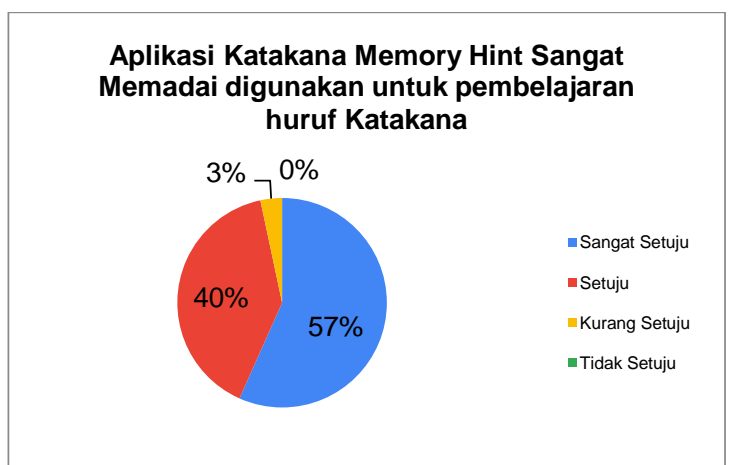

Gambar 2 : Respon angket Butir 2

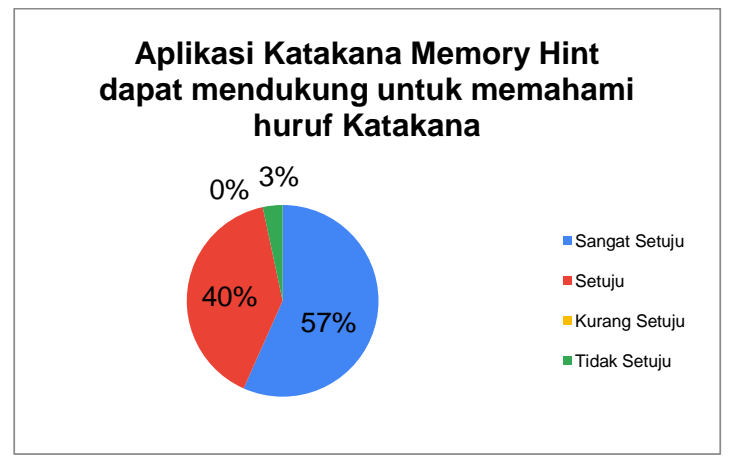

Gambar 3: Respon angket Butir 3

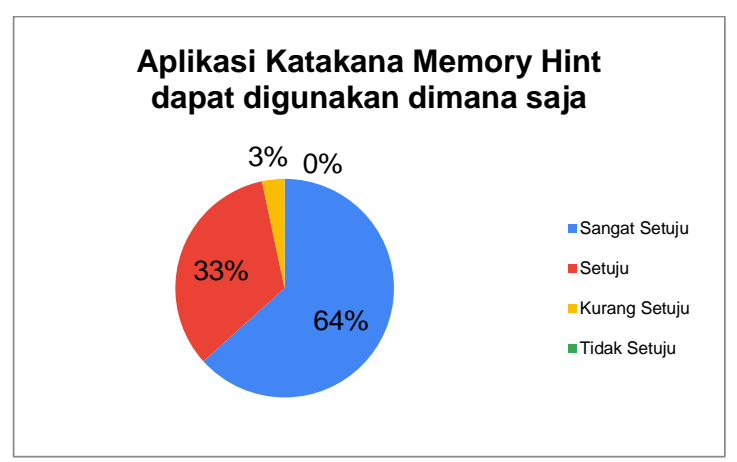

Gambar :4 Respon angket Butir 4
Materi Pelajaran yang terdapat di Aplikasi Katakana Memory Hint mudah untuk dimengerti

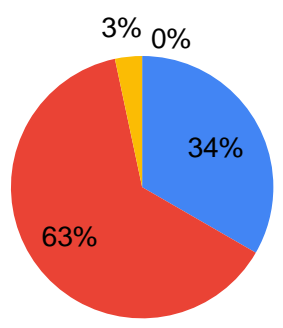

- Sangat Setuju

-Setuju

Kurang Setuju

- Tidak Setuju

Gambar 5: Respon angket Butir 5

Indikator 2: Motivasi mahasiswa sesudah memakai Aplikasi Andoroid Katakana Memory Hint

Pada Aplikasi Katakana Memory Hint, animasi, suara serta llustrasi mudah untuk dimengerti

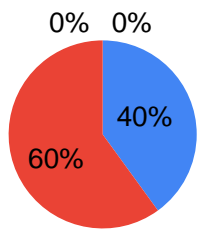

- Sangat Setuju

-Setuju

-Kurang Setuju

- Tidak Setuju

Gambar 6: Respon angket Butir 6

Aplikasi Katakana Memory Hint dapat mendorong saya untuk mempelajari huruf Katakana

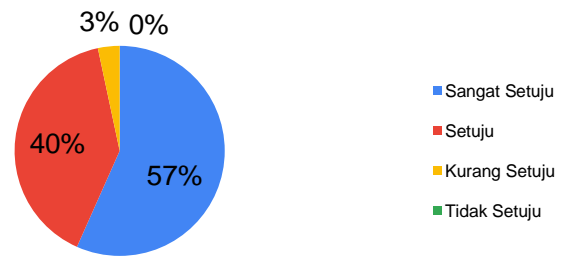

Gambar : 7 Respon angket Butir 7

Aplikasi Katakan Memory Hint sangat menyenangkan

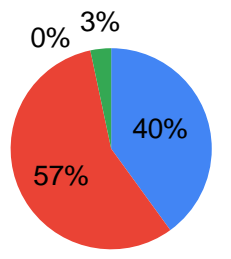

-Sangat Setuju

- Setuju

\#Kurang Setuju - Tidak Setuju

Gambar 8: Respon angket Butir 8 
Tersedia online di http://ejournal.undip.ac.id/index.php/kiryoku

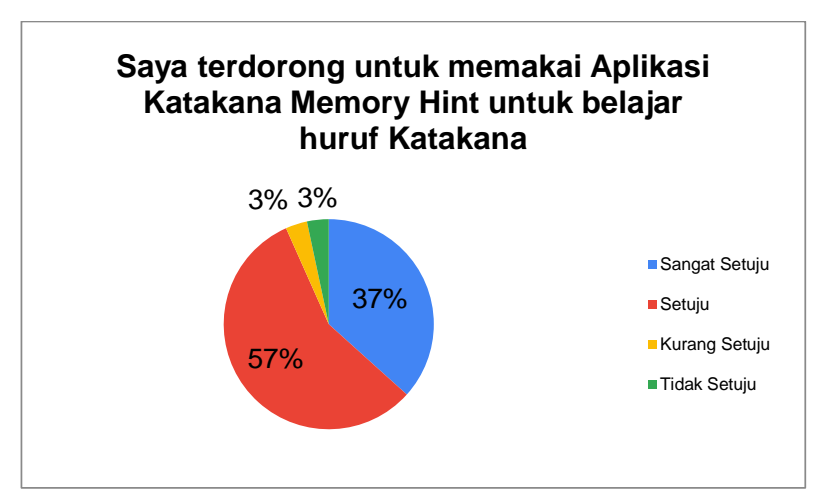

Gambar 9: Respon angket Butir 9

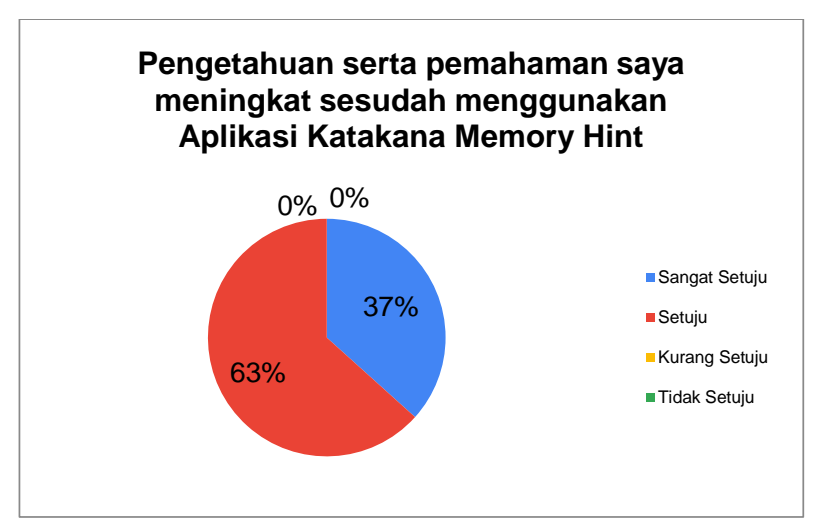

Gambar : 10 Respon angket Butir 10

Sesudah dilakukan perhitungan terhadap angket penelitian yang telah disebarkan kepada responden, respon angket yang didapatkan pada indikator 1 , dapat terlihat bahwa umumnya mahasiswa menjawab sangat setuju dan setuju terhadap pemakaian aplikasi Andoroid Katakana Memory Hint. Jadi, dapat simpulkan aplikasi Katakana Memory Hint dapat dikatakan efektif dipakai dalam mata kuliah Shokyuu Moji Goi Zenhan pada pembelajaran huruf Katakana. Pada indikator 2 tentang motivasi mahasiswa sesudah menggunakan aplikasi Andoroid Katakana Memory Hint, umumnya juga diperoleh jawaban yang positif dari mahasiswa sangat setuju dan setuju, jadi bisa dikatakan bahwa aplikasi Katakana Memory Hint dapat memotivasi mahasiswa untuk belajar huruf khususnya huruf Katakana.

\section{Penutup}

Pemakaian aplikasi Katakana Memory Hint efektif dalam peningkatan pada pembelajaran huruf Katakana pada mata kuliah Shokyu Moji Goi Zenhan semester Juli - Desember 2020 di Prodi pendidikan bahasa Jepang Universitas Negeri padang. Hasil Eksperimen menunjukkan terdapat perbedaan nilai rata rata pretest dan postest. Mahasiswa memperoleh bilai rata-rata prestest adalah 54,23 , terdapat nilai yang paling tinggi adalah 82 dan nilai yang paling rendah adalah 24. Sedangkan nilai rata-rata postest mahasiswa adalah 83,53 , terdapat nilai yang paling tinggi adalah 98 dan nilai paling rendah adalah 60 setelah dilakukan uji coba menggunakan aplikasi Katakana Memory Hint. Dari hasil angket yang diberikan terhadap 30 orang sampel penelitian dapat diambil kesimpulan penggunaan aplikasi Katakana Memory Hint dalam mata kuliah Shokyuu Moji Goi Zenhan memperoleh respon positif dan respon yang sangat baik dari mahasiswa. Bisa dikatakan hampir keseluruhan mahasiswa suka mempelajari huruf Katakana dan menggunakan Katakana Memory Hint. Hal ini dikarenakan pemakaian aplikasi Katakana Memory Hint sangat menyenangkan, memiliki animasi, suara, serta ilustrasi yang mudah dimengerti untuk menghapal serta mengingat huruf Katakana sehingga pemakai aplikasi Katakana memory Hint dapat dijadikan suatu arternatif sebagai media pembelajaran huruf Katakana bagi peneliti, mahasiswa dan seluruh pembelajar beserta orang-orang yang berkecimpung dalam bahasa Jepang.

\section{Referensi}

Aribowo, Eric K. 2015. Quizlet : Penggunaan Aplikasi Smartphone untuk Siswa dalam Mendukung Mobile Learning. Seminar Nasional Pendidikan Bahasa Indonesia 2015. 
Tersedia online di http://ejournal.undip.ac.id/index.php/kiryoku

Barakati, Dijey Pratiwi. 2013. Dampak Penggunaan Smartphone dalam Pembelajaran Bahasa Inggris. Jurnal Mahasiswa Fakultas Sastra Universitas Sam Ratulangi, Vol 1 No. 1. Hal 1-11.

Hardiansyah, Septian. 2012. Identifikasi Kesulitan Mempelajari Bahasa Jepang Pada Siswa SMA Islam Sudirman Ambarawa. Chi'e: Journal of Japanese Learning and Teaching 1 (1) (2012

J.Sasmita, Muryani., dan Tee Han Hook. 2019. Bahasa Jepang Itu Gampang. Yogjakarta : Pusat Kajian Bahasa Bahasa.

Mustika, Siska. 2017. Keefektifan Aplikasi Android 'Kanji Memory Hint dalam Meningkatkan Kemampuan Membaca dan Menulis Kanji. Skripsi :Program Studi Pendidikan Bahasa Jepang Universitas Muhammadiyah Yogyakarta

Rasiban, Linna M. 2017b. Mnemonic Image Based Mobile learning To Help Japanese Students lear Japanese Kanji Characers. Preceeding ICELA, May 2017.

Sadewa, Yoel. 2019. Bahasa Jepang Yang Mudah Yasashi Nihongo. Yogyakarta : Pustaka Widyatama

Sugiono. 2013. Metode Penelitian Pendidikan: Pendekatan Kuantitatif, Kualitatif, dan $R$ \& D. Bandung: Alfabeta.

Amat, R., Sari, J. Y., \& Ningrum, I. P. (2017). Implementasi Metode Local Binary Patterns Untuk Pengenalan Pola Huruf Hiragana dan Katakana Pada Smartphone. JUTI: Jurnal Ilmiah Teknologi Informasi, 15(2), 162-172.

Gifary, S. (2015). Intensitas Penggunaan Smartphone Dan Perilaku Komunikasi (Studi Pada Pengguna Smartphone di Kalangan Mahasiswa Program Studi
Ilmu Komunikasi Universitas Telkom). Jurnal Sosioteknologi, 14(2), 41719.

Jianti, M., Renariah, R., \& Rasiban, L. M. (2016). Efektivitas Model Pembelajaran Kooperatif Tipe Round Table Dengan Media Gambar Dalam Pembelajaran Kanji Dasar. EDUJAPAN, 1(1), 83-93.

KOMINFO. (2017). Survey Penggunaan TIK 2017.

Kurniasih, E. (2016). Efektivitas ELearning Aplikasi “Katakana Memory Hint" Dalam Pembelajaran Membaca Huruf Katakana: Penelitian pada Siswa Kelas X SMA PGRI 1 BANDUNG. Universitas Pendidikan Indonesia.

Mulyana Adimihardja, dkk. (n.d.). Bahasa Jepang Dasar: Hiragana Katakana. Humaniora Utama Press. https://books.google.co.id/books?id= Y0vNDwAAQBAJ

PAPILAJA, J. (n.d.). Pengenalan Tulisan Hiragana Dan Katakana Ke Dalam Tulisan Romaji Menggunakan METODE BACKPROPAGATION. 